\title{
Adaptation strategies against growing environmental and social vulnerabilities in mountain areas
}

\author{
Narpat S J odha
}

\begin{abstract}
This paper deals with the strategies adopted by the Hindu Kush Himalayan (HK-H) mountain communities in response to adverse natural and human induced circumstances. The quality of life and growth options in mountains (including hills) are deeply rooted in mountain specificities (e.g., fragility, marginality, diversity). Hence, the disregard of these mountain specificities while using mountain resources reduces communities' options and makes them more vulnerable to environmental and economic distresses. The paper first introduces the concept of vulnerability and the traditional low-intensity system of resource use. It then deals with the decline of such traditional systems due to the intensification of resource use caused by the integration of the relatively isolated mountain areas into mainstream economies. The paper concludes with a call for introduction of macro level policies to: (i) Minimize the vulnerability potential of globalization and global environmental change and (ii) Enhance local capacities to withstand and adapt to the changes promoted by these global processes. This discussion covers larger part of the present paper.
\end{abstract}

Vulnerability of an entity refers to its inability to withstand the stress caused by change. While environmental vulnerability is rooted in the biophysical features of a region or an ecosystem (e.g., mountain areas) and the responses of biophysical features when disturbed by natural forces or manipulated though human interventions (Kasperson et al. 1995). The social (socioeconomic) vulnerability is linked to the nature and range of livelihood options available to the people. Thus, fewer the usable options, greater is the vulnerability of a group. The inability of a community to effectively tackle the natural and socioeconomic circumstances results in reduced range of options (Blaikie and Brookfield 1987).

In fragile resource zones, such as the mountains, the process and factors generating environmental and social vulnerabilities tend to reinforce each other. Hence, policies aiming to address vulnerability will be successful only when they:

a. Consider specific biophysical features of mountain areas and their imperatives

b. Look at the imperatives as factors affecting mountain ecosystem's ability to withstand stresses, especially those caused by human interventions

c. Identify the livelihood affecting circumstances created by the natural features of mountain areas and human adaptations to risky and limited range of options created by them

d. Enhance aforementioned range of options by overstepping the limits imposed by vulnerability-creating circumstances of mountain ecosystems

e. Lookat the whole dynamics of human (economic) processes accentuating the vulnerability enhancing incentives

As a part of this we look in to the factors and processes associated with global environmental change and economic globalization, which have created new set of circumstances accentuating vulnerabilities in mountain areas; and required strategies against them.

\section{Vulnerability enhancing features and adaptations in mountain area}

Due to their biophysical conditions, mountain areas are characterized by high degree of fragility, marginality, limited accessibility, diversity, specific niche resources/products, and specific human adaptation mechanisms. Their causative factors are indicated in Table 1. The way these features influence the nature-society interaction (i.e., the type and intensity of human activities and the nature's responses there to) in terms of resource degradation, followed by yet another round of human action (e.g., further resource use intensification to meet scarcity), and nature's responses (e.g., further degradation) shape the interactive links between environmental and socio-economic vulnerabilities.

Due to their fragility (caused by slope, altitude, sensitivity to seismic activities etc.), the vulnerability of the Hindu Kush Himalayan $(\mathrm{HK}-\mathrm{H})$ mountains is easily amplified by natural forces such as mass wasting, flush floods, glacier melting, earthquakes etc. However, this paper primarily focuses on natural vulnerabilities which create socio-economic vulnerabilities and in turn become aggravated by the latter (by side effects of efforts to overcome the socio-economic vulnerabilities). In such situations, efforts to enhance sustenance options result in to reduced options.

\section{Risky and limited range of options}

In the context of socio-economic vulnerability, the mountain circumstances can be seen as the cause of risky and limited range of earning and sustenance options for mountain communities. Thus, due to fragility, some mountain areas cannot withstand the activities involving high resource use (which is often associated with increase in productivity) and creation of infrastructure (which could catalyze resource use intensification). Because of relative isolation, mountain communities are unable to fully harness "niche opportunities", which could enhance the range of earning options. Inaccessibility and isolation restrict the access and hence, the reliance on external support and force the mountain communities to depend on the limited options and local resources.

Furthermore, these circumstances (i.e., isolation, etc.) make mountain communities less prepared and weaker while interacting and exchanging with mainstream economies/ societies. Once integrated with the latter, they acquire 


\section{POLICY AND DEVELOPMENT}

TABLE 1. Mountain specificities and their indicative vulnerability related imperatives

Limited accessibility

\begin{tabular}{lll}
\hline Product of & - & Slope, altitude, terrain, seasonal hazards, and so on (and lack of prior investment to overcome them) \\
\hline Manifestations and implications & - & Isolation, semi-closeness, poor mobility, high cost of: mobility, infrastructural logistics, support systems, and \\
(i.e., promoting vulnerability and & & production/exchange activities \\
poverty-circumstances) & - & Limited access to, and dependability of, external support (products, inputs, resources, experiences) \\
& - & Detrimental to harnessing niche and gains from trade, invisibility of problems/ potentials to outsiders \\
\hline Imperative (appropriate & - & Local resource centred, diversified production/consumption activities fitting to spatial and temporal \\
responses, adaptation & & opportunities and constraints \\
approaches to reduce & - Local regeneration of resources, protection, regulated use, recycling etc. \\
vulnerability and poverty) & - Low-weight/volume and high-value products for trade \\
& - & Nature and scale of operations as permitted by the degree of accessibility/ mobility and local availability of \\
& resources \\
& - Development interventions with a focus on: \\
& Decentralization and local participation: reduction of inaccessibility with sensitivity to other mountain \\
& conditions (e.g., fragility) and changed development norms and investment yardsticks
\end{tabular}

Fragility and marginality

\begin{tabular}{ll}
\hline Product of & $\begin{array}{l}\text { Combined operations of slope/altitude, and geologic, edaphic, and biotic factors; biophysical constraints } \\
\text { (create socio-economic marginality) }\end{array}$ \\
\hline
\end{tabular}

Manifestations and implications (i.e., vulnerability and poverty promoting circumstances)

- $\quad$ Resources vulnerable to rapid degradation, unsuited to intensification, use of costly inputs; low carrying capacity

- Limited, low productivity, high risk production options; little surplus generation or reinvestment and subsistence orientation preventing high cost-high productivity options, disregard by 'mainstream' societies

- High overhead cost of resource use, infrastructural development; leading to permanent under-investment or selective investment for exploiting niche for mainstream economy

- People's low resource capacity preventing use of costly options for resource upgrading and production

- Socio-political-marginality of communities and their disregard by 'mainstream' societies

Imperatives (i.e., appropriate responses, adaptation approaches to reduce vulnerability and poverty

- Upgrading resources (e.g., by terracing) and regulation of usage

- Focus on low intensity, high stability in resource use

- Diversification involving a mix of high and low intensity uses of land, a mix of production and conservation measures with low cost

- Local regeneration of resources, recycling, regulated use, dependence on nature's regenerative processes and collective regulatory measures/institutions

- $\quad$ Different norms for investment to take care of high overhead costs

- Special focus on more vulnerable areas and people and their demarginalisation/empowerment

Diversity and niche

\begin{tabular}{|c|c|}
\hline Product of & $\begin{array}{l}\text { - Interactions between different factors ranging from elevation to soils and climatic conditions, as well as } \\
\text { biological and human adaptations to them, uniqueness of environmental resources and human responses }\end{array}$ \\
\hline $\begin{array}{l}\text { Manifestations and implications } \\
\text { (i.e., potential for vulnerability } \\
\text { and poverty reducing activities) }\end{array}$ & $\begin{array}{l}\text { - A basis for spatially and temporally diversified and interlinked activities conducive to sustainability, strong } \\
\text { location specificity of production and consumption activities limiting the scope for large-scale operation } \\
\text { - } \quad \text { Potential for products, services, activities with comparative advantages }\end{array}$ \\
\hline $\begin{array}{l}\text { Imperatives (i.e., appropriate } \\
\text { responses, adaptation } \\
\text { approaches to harness } \\
\text { vulnerability poverty-reducing } \\
\text { opportunities) }\end{array}$ & $\begin{array}{l}\text { - Small-scale, interlinked, diversified production/consumption activities differentiated temporally and spatially for } \\
\text { fuller use of environment } \\
\text { - } \quad \text { diversified and decentralized interventions to match diversity } \\
\text { - Equitable external market links; infrastructural development and local capacity building to guide the mountain } \\
\text { development interventions and harness the opportunities }\end{array}$ \\
\hline
\end{tabular}

Source: Table adapted from J odha (1998) and based on evidence and inferences from over 60 studies referred to by J odha and Shrestha (1993)

marginality status vis-à-vis the mainstream society, with several negative implications for mountain communities such as the over exploitation of mountains' niche for mainstream economies and the transfer of mountain niche at unfavorable terms of trade for mountain areas (Jodha 1998).

Diversity (and the consequent diversification of resource use) is an important factor responsible for health and stability of mountain environment as well as sustenance options for the mountain communities. However, by restricting the scope for several high pay off, option promoting activities requiring larger scale and specialization, it tends to reduce the range of options and increases vulnerability. This way, the natural vulnerabilities lead to social vulnerabilities (in terms of reduced range of livelihood options). Table 2 briefly summarises the relevant details. 
TABLE 2. Mountain features shaping the vulnerability related circumstances and the conditions generally associated with high economic performance or enhanced adaptation options against vulnerability

\begin{tabular}{|c|c|c|c|c|c|c|c|}
\hline \multirow[b]{3}{*}{ Vulnerability enhancing/ reducing mountain features } & \multicolumn{7}{|c|}{ Conditions/processes conducive to increased adaptation options } \\
\hline & \multicolumn{4}{|c|}{ Option-enhancing production factors } & \multicolumn{3}{|c|}{ Option-enhancing external links } \\
\hline & $\begin{array}{l}\text { Resource- } \\
\quad \text { use } \\
\text { intensificat- } \\
\quad \text { ion }\end{array}$ & $\begin{array}{l}\text { Input } \\
\text { absorption } \\
\text { capacity }\end{array}$ & $\begin{array}{l}\text { Infrastruc- } \\
\text { ture } \\
\text { facility }\end{array}$ & $\begin{array}{l}\text { Scale- } \\
\text { economies }\end{array}$ & $\begin{array}{l}\text { Surplus } \\
\text { genera- } \\
\text { ion/trade }\end{array}$ & $\begin{array}{l}\text { Replicating } \\
\text { external } \\
\text { experiences }\end{array}$ & $\begin{array}{l}\text { Attracting } \\
\text { external } \\
\text { attention/ } \\
\text { support }\end{array}$ \\
\hline $\begin{array}{l}\text { Limited Accessibility: Distance, semi-closeness, high cost of } \\
\text { mobility and operational logistics, low dependability of external } \\
\text { support, or supplies }\end{array}$ & $(-)^{a}$ & $(-)$ & $(-)$ & $(-)$ & $(-)$ & $(-)$ & $(-)$ \\
\hline $\begin{array}{l}\text { Fragility: Vulnerable to degradation with intensity of use, low } \\
\text { productivity/pay-off options }\end{array}$ & $(-)$ & $(-)$ & $(-)$ & & $(-)$ & $(-)$ & $(-)$ \\
\hline $\begin{array}{l}\text { Marginality: Limited, low pay-off options; resource scarcities and } \\
\text { uncertainties, cut off from the 'mainstream' }\end{array}$ & & $(-)$ & $(-)$ & $(-)$ & $(-)$ & $(-)$ & $(-)$ \\
\hline $\begin{array}{l}\text { Diversity: High location specificity, potential for temporally and } \\
\text { spatially inter-linked diversified products/activities }\end{array}$ & $(+)^{\mathrm{a}}$ & $(+)$ & & $(-)$ & $(+)$ & $(-)$ & $(-)$ \\
\hline $\begin{array}{l}\text { Niche: Potential for numerous, unique products/ activities } \\
\text { requiring capacities to harness them }\end{array}$ & $(+)$ & $(+)$ & & $(+)$ & $(+)$ & $(-)$ & $(+)$ \\
\hline $\begin{array}{l}\text { Human adaptation mechanisms: traditional resource management } \\
\text { practices-folk agronomy, diversification, recycling, demand } \\
\text { rationing, etc. }\end{array}$ & $(+)$ & $(+)$ & & $(-)$ & & $(t)$ & $(-)$ \\
\hline
\end{tabular}

a $(-)$ and $(+)$ respectively indicate "extremely limited" and "relatively higher degree" of convergence between imperatives of mountain features and the conditions associated with high degree of livelihood options/adaptation options. To enhance the earning opportunities as adaptations options against vulnerabilities the degree of convergence indicated by $(+)$ has to be increased. This would involve (i) enhanced accessibility, (ii) upgrading and development of fragile/marginal lands or evolve high pay off activities suited to them; (iii) demarginalisation and empowerment of mountain communities; (iv) harnessing of niche and high pay off diversified activities with equitable local gains and $(v)$ build upon indigenous knowledge combined with R\&D based scientific measures to evolve resource management usage systems with high returns. All this needs greater understanding of mountain situation. Source: Table adapted from J odha (1997) applicable to different sectors in mountain areas

\section{Traditional two-way adaptation system}

The mountain people are acquainted with the above circumstances (except perhaps the side effects of increased physical and economic integration of mountain areas with the mainstream economies), and through trials and errors over the generations have evolved several practices and measures to promote and enhance the range of survival and growth options. Historically mountain communities have tried to reduce bio-physical as well as socio-economic vulnerabilities by means of a two way adaptation process:

- Adjusting their demands to restrictions imposed by mountain circumstances;

- Adapting mountain conditions to their needs through practices such as terracing to cultivate on fragile slopes (Jodha 1998).

These patterns are still visible in remote and isolated mountain areas.

\section{The process of change: Resource use intensification and weakening of traditional adaptations}

While the two way adaptation process helped reduce vulnerabilities in the subsistence economic context, it was largely supply driven (i.e.,, demand was adjusted to supply conditions): Hence, it faced a gradual decline once resource use system and production processes became demand driven (when the mountain areas were integrated with the mainstream economies). As a result, mountain resources were exposed to serious degradation and depletion through inappropriate intensification and over extraction induced by increased demands. In most areas, this degradation led to a reduction in the range of local resource-based earning options. The major consequences of the integration with mainstream economies (as summarized under Table 3) are briefly noted below. For details see Jodha (1998).

\section{(a) Integration and impacts on coping mechanisms}

While integration with mainstream economies have led to a various gains including availability of growth opportunities, several indicators show that it has also led to a decline in traditional coping mechanisms. This is a serious problem communities where equally dependable alternative options have not been created.

(b) Shift from supply-driven to demand-driven resource use systems The most important consequence of improved links between mountain communities and the mainstream economies is the shift of resource use/production systems from being supplydriven-to being demand-driven. Accordingly, the integration process has promoted increased resource extraction in order to meet external and internal demands. This change has made the mountain areas more vulnerable both environmentally as well as in a socio-economical context. The process applies to both traditional farming systems as well to larger resource extraction system for niche-resources (forest, mineral, hydropower etc.), to meet the mainstream systems' demands. Loss of resource regenerative practices, diversification measures, combining production and conservation needs etc. are well known unsustainability and vulnerability promoting responses to 
TABLE 3. Vulnerability related impacts of closer integration of mountain areas into mainstream economies*

\section{Positive impacts}

Enhanced range of livelihood options helping in adaptations to vulnerability through:
- Increased access to external supplies, markets, employment (productive migration), social transfers (welfare and relief), investable resources etc.

- Increased internal production cum exchange opportunities through investments, technologies infrastructural facilities etc.

- $\quad$ Scope for harnessing unique opportunities (niche resources) and gains from trade.

- Increase in local capacities to harness new opportunities.

\section{Negative side effects}

Enhanced risks of increased environmental and social (economic) vulnerabilities through:

- Increased pressure of internal and external demand on mountain resources, over extraction.

- $\quad$ Strong extractive focus of development policies and market forces on selective niche-resources/products of mountains (e.g., timber, mineral, hydropower etc.) exposing mountains to greater environmental degradation, reduced resource regeneration and productivity.

- $\quad$ Resource exploitation to primarily meet the needs of mainstream economy, ignoring the local social and environmental concerns and by-passing the non- niche resource areas/activities.

- Imposition/extension of externally evolved inappropriate technological and institutional interventions: (i) Promoting indiscriminate resource intensification, and narrow specialization, and (ii) Marginalizing the traditional resource use practices and institutional arrangements designed to guard against environmental/economic risks.

- Marginalization of mountain communities and their concerns with little participation in mainstream decisions/actions about mountains.

- Increased high land - low land economic links with unfavorable terms of trade for mountains.

- $\quad$ Persistent poverty and low skills/capacities and resources to benefit from development interventions; and widening intra-mountain area disparities i.e., between accessible and less accessible areas.

\footnotetext{
* Uneven but increased integration of mountain areas with mainstream economy through physical infrastructure, market, development intervention, and
} administrative controls. Source: Table based on evidence observations, and inferences from over 40 studies from different countries of HK-H region.

increasing demands by ignoring the natural limits to supply.

\section{(c) Marginalization of traditional sources of resilience}

Integration also led to marginalization and disappearance of several indigenous knowledge systems, folk agronomic practices, collective risk sharing arrangements and several locally evolved and enforced institutional arrangements that have been safeguarding against vulnerability promoting processes. This resulted from external interventions (of technological and institutional nature) in mountain areas without sufficient understanding and consideration of mountain specific conditions. Most of them emerged as side effects of mountain development without mountain perspective. Particularly, since 1950s, when state assumed the responsibility of welfare and development, the external interventions and plain-based experiences were imposed on mountain areas, which in most cases disrupted the traditional adaptation practices and measures without providing effective substitutes (Jodha 2002).

\section{Adaptation options in the changed context}

Despite the fact that traditional adaptations against vulnerabilities have been marginalized, integration has resulted in generating new coping strategies and adaptation options against vulnerabilities, particularly in mountain areas with better access and high production potential.

As far as natural disasters are concerned, degree of vulnerability has been reduced because external support and supplies means that communities no longer have to fend for themselves. Besides, the subsidies and support systems for production activities have also helped in enhancing sustenance and development options. Himachal Pradesh in India, Ninang and Kunming areas in China, Ilam district in Nepal and Northern territories Pakistan are same examples of places where earnings through various production and marketing activities have substantially increased. A number of sources of vulnerabilities rooted in limited accessibility, marginality, fragility etc. are also controlled in many areas though infrastructural development, resource-development, improved market links, new technologies and income enhancing activities.

However, the access and use of new potential adaptation options are not uniformly available to all mountain areas. Consequently, intra-mountain and inter-community differentiations have significantly increased. The remote and marginal areas have not benefited in terms of enhanced options (Jodha 2001a)

More importantly, a number of new options have increased mountain communities' dependence on external support and charity; their access and control over local natural resources has declined.

Besides, new options invariably involve intensification of resource use and over-extraction of mountain niche and their supplies to downstream economy with unfavorable terms of trade to mountains. Consequently, one observes a range of emerging indicators of unsustainability of existing patterns of resource use. Thus unless sensitized to mountain conditions, the present approaches promoting adaptations against vulnerabilities may enhance the extent of the latter. Some indicators of the same are already visible in many areas (Jodha et al. 1992). The current trends indicating resource use intensification driven by economic globalization and global environmental change may accentuate the loss or unreliability of newly promoted adaptation options, as discussed below. 


\section{New sources of growing vulnerabilities and needed adaptation strategies}

As mentioned in previous discussion, a major shift is evident when one compares the traditional and present day source and adaptation to vulnerability. While the local (communitylevel) perceptions and practices were responsible for the assessment and defenses against vulnerabilities in the past, it is now macro-level, with external links and intervention becoming more important in promoting both vulnerabilities and the options against them. Furthermore, the external factors acted as yet another contextual variable, to which local communities had to adapt. As a result of the above shifts, the macro-level public policies have become an important locus for identification and promotion of adaptation strategies against vulnerabilities in mountain areas. This becomes clear once one looks at the sources of growing vulnerabilities associated with economic globalization and global environmental change.

In the following paragraphs, we will discuss the role of global environmental changes in accentuating vulnerabilities as well as its repercussions in the context of the Hindu Kush Mountains. The discussion draws upon the issues and analysis elaborated by Jodha $(2000,2001 b)$.

\section{Global environmental changes: Skewed perspectives}

There are two types of global environmental changes namely 'systemic type' and 'cumulative type' (Turner et al. 1990, Kasperson and Kasperson 2001, Kasperson et al. 1995). Broadly speaking, a systemic change is one that, while taking place in one locale, can affect changes in systems elsewhere. The underlying activity need not be widespread or global in scale, but its potential impact is global in that it influences the operation and functioning of the whole system. Emissions of $\mathrm{CO}_{2}$ from limited activities that have impacts on the great geospherebiosphere system of the Earth and causing global warming offer a prime example. The cumulative type of change refers to localized but widely replicated activities where changes in one place do not affect changes in other distant places. When accumulated, however, they may acquire sufficient scale and potential to influence the global situation in various ways. Widespread deforestation, extractive land-use practices, ground water pollution/depletion, biodiversity loss etc. and their potential impacts on the global environment serve as examples. Both types of changes are the products of naturehuman interactions and are linked to each other in several ways.

However, despite several uncertainties and information gaps especially in the regional contexts, mainly due to domination of the discourse by natural science groups working on climate change and the high noise potential of issues debated (e.g., dooms-day predictions), the 'systemic type' of environmental change has received greater attention and resource allocation for research and policy advocacy in the global fora. Thus, until recently, the 'cumulative type', despite more concrete evidence, certainties of impacts and possibilities of well-focused remedial/adaptive measures, received limited attention. This has led to 'skewed perspectives' on the whole subject of global environmental change (Jodha 2001b). The major consequence of this imbalance has been the lesser attention to more practical and concrete options to address global environmental issues.

\section{Cumulative environmental change}

While the mountain areas are subject to both types of changes, due to elevation related features, the impacts of systemic changes is more readily visible (e.g., through glacier melting due to warming; upward shift of certain plant species; distortion of flowering seasons for fruits such as hill apples etc.). However, for the reasons stated above and their greater visibility to communities, the cumulative type of changes should get greater attention, especially in the short run. In the place-based contexts these changes not only more readily expose the communities to higher risks and vulnerabilities, but they get further reinforced by people's efforts (through resource use intensification etc.) to face the emerging risks and scarcities.

In short, the environmental risks and vulnerabilities of a system, such as a mountain ecosystem, can be understood in terms of instability or destruction of (a) natural resources, (b) their productivity potential, and (c) largely invisible processes represented by the biophysical functions and flows categorized as regeneration, variability-flexibility, resilience, nature's cycles, or energy and material flows. The environmental risks and people's vulnerabilities in terms of reduced adaptation options can be identified with a negative change in any of the three categories of variables. Ultimately, however, the extent and nature of environmental risk and vulnerabilities relate to disruptions in the biophysical functions and flows (which in mountain regions are very much linked to imperatives of mountain specificities (see Table 1).

Traditionally, the mountain communities would guard against such risks and vulnerabilities through folk agronomic and institutional practices such as diversified farming. These adaptations involved various other practices - such as product recycling, flexible consumption patterns, transhumance and migration - that directly or indirectly facilitated regulation of pressure on resources and, hence, proved conducive to the operation of biophysical processes for environmental stability. However, these land-extensive, non-extractive features of traditional systems are incompatible with the resource-use intensification forced by rising internal and external demands on mountain resources.

Inappropriate intensification of resource use disrupts the above functions and exposes the environment to serious degradation. This process manifests the cumulative type of global environmental change. It's more popularly understood or projected components are deforestation, overgrazing, extension of cropping to steep and fragile slopes, landslides and mudslides, periodic flash floods, soil erosion, disappearance of vital biophysical resources, and reduced resource productivity. Some of these have been documented as emerging indicators of unsustainability in HK-H region.

The levels of environmental instability, risks and vulnerabilities, which are already quite serious, are further accentuated with the impacts of global systemic change (e.g. global warming), and economic globalization.

\section{Impacts of systemic changes}

Compared to the information on cumulative changes, there is a dearth of details on the potential systemic changes affecting mountain areas. With full recognition of the limitations of the regional information on systemic changes (e.g., their conjectural nature and associated uncertainties of predicted change scenarios), however, a few possibilities may be stated. Accordingly, the potential changes in the Hindu Kush- 
Himalayas resulting from global warming, as summarized by different studies (Topping et al. 1990, ICIMOD 1993, IPCC 2001) include the following:

(i) Forests may have both quantitative and qualitative changes. Some of the species may disappear; others may move spatially. This may accentuate the already known current negative trends relating to forest areas. The resulting reduced biodiversity may influence both biophysical functions and flow governing environmental stability, thereby making the economy and survival strategies of people more vulnerable to risks.

(ii) The region may have higher rainfall (convective, highintensity rains), which may cause increased runoff, flash floods, soil erosion, and mud- and landslides, and could influence overall farming systems. This will adversely affect people's survival strategies as well as the basic biophysical functions of the area.

(iii) Increased warming would lead to increased snow-melting and consequent disturbance to hydrological cycles, seasonality of flows of water, and related impacts on land use and cropping intensities, disturbing the already threatened diversity and sustainability of mountain resource use. The environmental risks will, thus, be further accentuated.

(iv) To the potential changes one may add a few more possibilities. They include probable changes in the specific mountain conditions (such as fragility, diversity, or niches) and in their interrelationships; these changes may generate new constraints and opportunities, influencing the comparative advantages of mountains and their links with other regions, and perspectives of public interventions in mountain areas. At the microlevel, the agricultural systems covering all land-based activities may undergo several changes, including disturbance to well-adapted cultivars and management practices, product and income flows, and people's strategies for coping with risks (Jodha 1989, 1995). These changes, in turn, may influence resourceuse patterns, with implications for environmental stability.

The above changes may result in increased compulsions or incentives for resource-use intensification, which may accelerate the already observed cumulative changes and their impacts on vital biophysical processes and flows; thereby affecting the adaptation options against vulnerability. Table 4 presents some possibilities of current trends in resource degradation (cumulative changes) likely to be accentuated by systemic changes. The impacts of the combined two types of changes on biophysical processes and nature's flows are indicated by the capital letters in Table 4.

\section{Environmental change and social vulnerabilities}

The final consequence of the changes mentioned above is reflected in reduced livelihood options for mountain communities and hence increased extent of vulnerabilities (see Table 5).

The socio-economic vulnerabilities at the operational level, are revealed by reduced range, viability, flexibility, dependability, and pay-offs of production and resource-use options to satisfy human needs. These problems may arise owing to the breakdown or infeasibility of diversified, resourceregenerative practices as well as to the degradation of the natural resource base. On the institutional side, a different degree of socio-economic vulnerability is exhibited by the slackening of resource-management/protection systems, reduced access to resources, the reduced range and quality of group activities, and the marginalisation of collective sharing systems as well community's collective stakes in local resources. Some of these problems arise from disruptions in environmental and naturalresource situations while others cause such disruptions, as when socio-economic adjustments to environmental change create further negative changes in the environmental situation at secondary or tertiary levels. Table 6 indicates these possibilities, which relate mainly to the predominant activity (i.e., agriculture) of mountain communities. Such formulation, however, can be present with respect to other activities.

Fuller understanding of risks and their processes may help identify and evolve adaptation measures. Framework and perception to address these and associated issues are elaborated for different regions in two very comprehensive volumes on the subject (Kasperson et al. 1995, Kasperson and Kasperson 2001). However, that falls outside the scope of this paper.

\section{Economic globalization and vulnerabilities}

Economic globalization with primacy to market friendly and market driven processes is spreading to all countries and regions. Though promoted as means to global growth and prosperity, the process also carries risks. The participants unprepared for the changes are likely to encounter more risks and limited gains in the process. The mountain communities like $\mathrm{HKH}$, due to their specific biophysical conditions and marginalization, fall under the above category. Due to disregard of the mountain imperatives while designing and implementing development efforts, the efforts have not led to substantial progress. Insensitivity of market processes to the imperatives of mountain conditions, while integrating mountain areas into wider economic systems may further the pattern of neglect. Besides, the rapid erosion of traditional coping strategies of mountain communities in the face of market driven technological and institutional changes, their inability to effectively participate in the same change process, and the reduced economic role and capacity of the state (due to market friendly economic reforms) to extend welfare and development support to them is going to make the communities more vulnerable.

Market and related changes are not new to mountain communities. But globalization differs from the past changes in terms of:

(i) Unprecedented primacy accorded to market and marginalization of the state and communities in economic and related decisions and processes

(ii) Reinforcement of the role of inter-connectedness of economic transaction (specially trade flows involving resources, products and services) globally helping the more competitive entities

(iii) Facilitative and speed promoting integrative role of information technology

(iv) The power accorded to formal institutions suchWTO, which promotes global perspectives at the cost of local concerns. With such features empowering the market forces, and also due to the spread of economic globalization to mountain areas, the nature and extent of vulnerabilities are rapidly changing. Even when most of the mountain products do not get into global trade, globalization influences mountain areas through major shifts in policies, programmes, priorities etc. adopted by the state in response to the incentives, obligations and compulsions created by market friendly arrangements promoted by agencies such as WTO, World Bank, IMF etc. at 
TABLE 4. Potential accentuation of cumulative environmental change under the impacts of systemic environmental changes

\begin{tabular}{|c|c|c|c|}
\hline \multirow[b]{2}{*}{$\begin{array}{l}\text { Current problem (cumulative type of change) likely } \\
\text { to be accelerated by systemic change }\end{array}$} & \multicolumn{3}{|c|}{ Potential key manifestation of systemic change (impacts of global warming) } \\
\hline & $\begin{array}{l}\text { Vegetation changes: forest } \\
\text { size, location, composition, } \\
\text { growth cycle, biodiversity, } \\
\text { interactive processes }\end{array}$ & $\begin{array}{l}\text { Increased convective rains: } \\
\text { floods, runoff, soil erosion, } \\
\text { changes in growing season, } \\
\text { hydrological cycle }\end{array}$ & $\begin{array}{l}\text { Warming-led snow melt: } \\
\text { increased water flows, soil } \\
\text { erosion, changes in hydrology } \\
\text { mountains and flood plains }\end{array}$ \\
\hline $\begin{array}{l}\text { Deforestation, vegetation degradation, reduced } \\
\text { diversity }\end{array}$ & $\mathrm{X} \quad(\mathrm{R}, \mathrm{F}, \mathrm{N}, \mathrm{S})^{\mathrm{a}}$ & & $\begin{array}{ll}\mathrm{X} & (\mathrm{R}, \mathrm{N}, \mathrm{F}) \\
\end{array}$ \\
\hline Soil erosion, landslides and mudslides, floods & & $(N, F, S)$ & $(\mathrm{N}, \mathrm{F})$ \\
\hline $\begin{array}{l}\text { Changes in land-use pattern, reduced diversity of } \\
\text { farming systems, increased resource-use intensity } \\
\text { and degradation }\end{array}$ & $X \quad(R, F, N)$ & $(\mathrm{S}, \mathrm{N})$ & \\
\hline $\begin{array}{l}\text { Increased vulnerability of people's survival } \\
\text { strategies to environmental instability due to } \\
\text { resource degradation and disruption }\end{array}$ & $X \quad(R, F)$ & $X \quad(R, F, S)$ & $X \quad(R, S)$ \\
\hline
\end{tabular}

a, biophysical processes and flow likely to be affected; R, regeneration; F, flexibility, variability; N, resilience; S, energy and material flows.

Source: Adapted from J odha (2001)

TABLE 5. Environmental change and socio-economic impacts promoting vulnerabilities in mountain areas

\begin{tabular}{|c|c|c|c|c|}
\hline \multirow[b]{2}{*}{$\begin{array}{l}\text { Environmental changes and } \\
\text { underlying factors or responses to } \\
\text { change }\end{array}$} & \multicolumn{4}{|c|}{ Socio-economic impacts/vulnerabilities ${ }^{a}$} \\
\hline & $\begin{array}{l}\text { Reduced: } \\
\text { feasibility of traditional } \\
\text { production systems, } \\
\text { regeneration, resilience }\end{array}$ & $\begin{array}{l}\text { Reduced range/quality of } \\
\text { livelihood options; control, } \\
\text { access to resources }\end{array}$ & $\begin{array}{l}\text { Increased external } \\
\text { dependency, subsidy } \\
\text { marginalization unequal } \\
\text { exchange }\end{array}$ & $\begin{array}{l}\text { Reduced collective } \\
\text { sharing (options) low } \\
\text { resilience, breakdown of } \\
\text { group action culture }\end{array}$ \\
\hline $\begin{array}{l}\text { Physical degradation of land } \\
\text { resources }(\mathrm{W}, \mathrm{S})^{\mathrm{b}}\end{array}$ & $x$ & $x$ & $x$ & $x$ \\
\hline $\begin{array}{l}\text { Reduced variability, flexibility of } \\
\text { production factors }(V, W)\end{array}$ & $x$ & $x$ & $X^{p}$ & \\
\hline $\begin{array}{l}\text { Increased "ecological" subsidization } \\
\text { through chemical, physical, } \\
\text { biological inputs }(V, W)\end{array}$ & & & $X^{p}$ & $X^{p}$ \\
\hline $\begin{array}{l}\text { Vicious circle of resource } \\
\text { degradation, overextraction- } \\
\text { degradation }(W, S)\end{array}$ & $x$ & $x$ & $x$ & \\
\hline $\begin{array}{l}\text { Niche, technology, market-induced } \\
\text { overextraction, reduced resource } \\
\text { availability/access }(\mathrm{V}, \mathrm{W}, \mathrm{S})\end{array}$ & & $x$ & $x^{p}$ & $X^{p}$ \\
\hline
\end{tabular}

global level. The consequent emergence of micro-level changes creates the circumstances that adversely affect the range and quality of options against vulnerability available to mountain communities. The specific processes and impacts (summarized under Table 6) are elaborated below. They are largely based on an exploratory study on impacts of globalization on fragile mountain areas and communities in selected areas of five countries in HK-H region (Jodha 2001b).

(a) Ignoring links between environmental and socio-economic vulnerabilities

There are visible incompatibilities between the mechanisms and driving forces of globalization and imperatives of mountain. While globalization calls for resource intensification, narrow specialization and over extraction for profitability, mountain imperatives call for diversified and interlinked activities which combine production and conservation concerns. This Vulnerability-wise incompatibility has the following implication:

While the changes promoted by globalization may result in economic gains, they disregard activities which promote environmental sustainability and stable economic options. Thus, the promoted options against economic vulnerability may promote environmental vulnerability. Since the new options differ significantly from traditional options, a decline in the range of time-tested options against vulnerability is imminent, especially when globalization is considered.

(b) Decline of social transfers and support systems

The vulnerability is further accentuated by the loss of welfare and development support due to the norms encouraged by WTO such as privatization, deregulation and structural reforms, which reduce the role of state and public sector. The net result is reduced employment and income as well as 


\section{POLICY AND DEVELOPMENT}

support through $R \& D$ and infrastructure related services in mountain areas.

(c) Erosion of niche-opportunities

'Niche' refers to resources activities/products having comparative advantage to mountain areas/people. Production of off-season vegetables; fruits NTFPs and seeds etc. are some examples. As shown by recent evidence from $\mathrm{HKH}$ countries, trade liberalization has led to the loss of 'niche' as a number of these products are produced in massive green houses in plains. Similarly a number mountain products (e.g., fruits and flowers) are losing to competition from these products from distant countries due to trade liberalization.

Finally, profitability and selectivity-based intensive exploitation as a result of globalization adversely affects the mountains' niche. This is because the products are partly results

TABLE 6. Potential vulnerability enhancing factors associated with globalization in mountain context and approaches to adapt to them

\section{Potential factors}

(a) Visible incompatibilities between driving forces of globalization and imperatives of specific features of mountain areas (fragility, diversity, etc.)

(b) Accentuation of negative side effects of past development interventions under globalization due to their common elements (approaches, priorities, etc.) with adverse effects on mountain areas

\section{Elaborations/Examples}

(i) Market driven selectivity, resource use intensification and over exploitation induced by uncontrolled external demand versus (ii) fragility-marginality induced balancing of intensive and extensive resource uses; diversification of production systems, niche harnessing in response to diversity of resources

Consequence: Environmental resource degradation loss of local resource, diversified livelihood options; increased external dependence.

Common elements between the past public interventions and market driven globalization:

(i) Externally conceived, top-down, generalized initiatives (priorities, programs, investment norms) with little concern for local circumstances and perspectives, and involvement of local communities

(ii) Indiscriminate intensification at the cost of diversification of resource use, production systems and livelihood patterns causing resource degradation (e.g., deforestation, landslide, decline in soil fertility, biodiversity)

(iii) General indifference to fragile areas/people excepting the high potential pockets creating a dual economy/society; over- extraction of niche opportunities (timber, mineral, hydropower, tourism) in response to external (mainstream economy) needs, with very limited local development

Consequence: Environmental degradation and marginalisation of local resource use systems, practices, and knowledge etc., likely to be enhanced due to insensitivity of market to these changes and gradually weakened public sector

(c) Globalization promoting erosion of provisions and practices imparting protection and resilience to marginal areas/ people (including disinvestment in welfare activities)

(i) Traditional adaptation strategies based on diversification, local resource regeneration, collective sharing, recycling, etc., likely to be discarded by new market-driven incentives and approaches to production, resource management activities

(ii) Shrinkage of public sector and welfare activities (including subsidies against environmental handicaps, etc.) depriving areas/people from investment and support facilities (except where externally exploitable niche opportunities exist)

Consequence: Likely further marginalisation of the bulk of the mountain areas and people.

(d) Loss of local resource access and niche-opportunities through the emerging "exclusion process"

Niche resources/products/services with their comparative advantage (e.g., timber, hydropower, herbs, off-season vegetables, horticulture, minerals, tourism etc.) and their likely loss under globalization through:

i) Market-driven over extraction/depletion due to uncontrolled external demand

ii) Focus on selective niche, discarding diversity of niche, their traditional usage systems, regenerative practices, indigenous knowledge

iii) Transfer of "niche" to mainstream prime areas through market-driven incentives, green house technologies, infrastructure and facilities (e.g., honey, mushrooms, flowers produced cheaper and more in green house complexes in the Punjab plains compared to naturally better suited Himachal Pradesh, India)

iv) Acquisition and control of access to physical resources: forest, water flow, biodiversity parks, tourist attractions by private firms through sale or auction by government, depriving local's access, destroying customary rights and damaging livelihood security systems.

Consequence: Loss of comparative advantages to fragile areas or access to such gains for local communities

(e) Adapting to globalization process, possible approaches to loss minimization i) Sharing gains of globalization through partnership in primary and value adding activities promoted through market; building of technical and organizational capacities using NGOs and other agencies including market agencies to promote the above

ii) Promotion of local ancillary units (run by locals) to feed into final transactions promoted by globalization; this needs institutional and technical infrastructure and capacity building

iii) Provision for proper valuation of mountain areas resources and compensation for their protection, management by local people for use by external agencies

iv) Enhance sensitivity of market-driven initiatives to environment and local concern to be enforced by international community and national governments

v) All the above steps need local social mobilization, knowledge generation and advocacy movements; and policy-framework and support

Consequence: If above steps are followed, there are chances of influencing the globalization process and reducing its negative repercussion for mountain areas/people

Source: Adapted from J odha (2000) 
of diversified and interlinked resource use systems that helps in maintaining the organic integrity, as well as health and productivity of the natural resource-base. Market driven patterns of resource use are insensitive to this aspect and hence selectively focus on individual component disintegrating the total system.

\section{(d) Exclusion process}

Mountain communities are losing their livelihood options and adaptation strategies against vulnerabilities due to an emerging "exclusion" process (i.e., making people resourceless and optionless). As a part of economic liberalization, privatization and deregulation promoted under globalization, the governments favour market agencies, especially those that can bring in foreign direct investment (FDI). As a part of this process, in $\mathrm{HKH}$ region, governments have acquired the community (and private lands) and given it to business firms in the name of promoting development. There are also other emerging trends showing communities deprived of their intellectual property rights.

Another facet of "exclusion process" is people's inability to participate in highly paying activities promoted by globalization. This applies mainly to those who are not well equipped or prepared to participate effectively in globalizationled changes or those who are unable to adapt quickly to the change.

\section{Potential opportunities}

Despite wide-spread criticism of economic globalization for its vulnerability-promoting effects, there are some potential opportunities to build adaptation strategies against the vulnerabilities. These opportunities include:

- Improved trade opportunities for mountain product such as specialty organic food and herbs

- $\quad$ Services such as mountain tourism, which will grow faster in the times to come

- Surable gainful opportunities for associating mountain people as ancillary partners with low land market agencies to harness opportunities created by globalization.
There are several scattered success stories indicating the above possibilities (Jodha 2002). The availability of investable funds and technologies for relating biophysical constraints in mountain areas is another possibility offered by globalization process.

However, the key constraint is the lack of knowledge about such possibilities and skills to harness them. Put differently, to begin with one should focus on "identification of options"- to minimize negative effects and harnessing of positive opportunities created by globalization. These options could form a part of regionally differentiated integrated coping strategy for mountain areas to wisely and effectively adapt to globalization. To build such a strategy, focused research in different mountain area is a first step. Guided by this concern ICIMOD has recently initiated work on "Globalization and Fragile Mountains" covering areas in five countries of $\mathrm{HKH}$ region.

\section{Adaptation strategies against enhanced vulnerabilities}

Basic considerations for adaptation strategies

The first important factor to be understood while evolving such strategies is that most of the present adaptation-option reducing circumstances are primarily rooted in the external, macro-level decisions and action (e.g., those promoting economic globalization and unintentionally encouraging and permitting environmental degradation). Hence, the adaptation strategies (which will create micro-level options) have to have strong elements of macro-policies and support systems.

Secondly, since one of the root causes of (option reduction) vulnerability promotion is indiscriminate intensification of resources, this has to be supplemented by high pay-off (high option generating) diversified, interlinked, and equitable natural resource use systems. This would call for focus on specific priorities and provisions at macro-policy levels, which can help build complementarities between diversification and intensification.

Third, sensitivity towards and involvement of community level stakeholders in the policy-programme interventions to

\section{TABLE 7. Indicative steps/measures to enhance adaptation options against vulnerabilities caused by cumulative type of global environmental change}

\begin{tabular}{|c|c|}
\hline Adaptation areas & Operational steps \\
\hline $\begin{array}{l}\text { Amending Incentive Structures that } \\
\text { promote demand pressure and over } \\
\text { extraction of environmental resources and } \\
\text { services (ERS) }\end{array}$ & $\begin{array}{l}\text { - Assessment, valuation and realistic costing of environmental resources and services } \\
\text { - Based on (a), (ERS) users pay to the protectors/conservators of ERS (e.g., low landers } \\
\text { compensating uplanders) } \\
\text { - Curtail "free riding" tendencies and practices }\end{array}$ \\
\hline $\begin{array}{l}\text { Recognition and space for place-based } \\
\text { (micro-level) perspectives, practices in } \\
\text { global discourse on ERS }\end{array}$ & $\begin{array}{l}\text { - To reduce disconnects between supply and demand side stakeholders in ERS } \\
\text { - To ensure on ground awareness and help concrete focus and action on option- } \\
\text { reducing ERS usage systems } \\
\text { - To promote local responsibilities of global stakeholders }\end{array}$ \\
\hline $\begin{array}{l}\text { Sensitivity towards and involvement of } \\
\text { communities in ERS related policy- } \\
\text { programmes }\end{array}$ & $\begin{array}{l}\text { - To help build bottom up participatory strategies and approaches to ERS issues } \\
\text { - Identify spatially differentiated steps to regulate ERS }\end{array}$ \\
\hline $\begin{array}{l}\text { Change focus of technological and } \\
\text { institutional interventions regarding ERS } \\
\text { issues }\end{array}$ & $\begin{array}{l}\text { - To promote complementarities between extensive and intensive types of resource use } \\
\text { - Upgrade, modify, and integrate components of traditional ERS management systems } \\
\text { in to modern ones }\end{array}$ \\
\hline
\end{tabular}




\section{POLICY AND DEVELOPMENT}

TABLE 8. Indicative steps/measures to enhance adaptation options against vulnerabilities caused by economic globalization processes

\begin{tabular}{|c|c|}
\hline Adaptation areas & Operational steps \\
\hline $\begin{array}{l}\text { Mechanisms to help mountain people } \\
\text { share gains of Globalization }\end{array}$ & $\begin{array}{l}\text { - Share in primary and value adding activities based on mountain-located opportunities promoted by } \\
\text { globalization } \\
\text { - } \quad \text { Partnership with external market agencies } \\
\text { - } \quad \text { Equitable terms of trade (compensation for mountain) } \\
\text { - Land product/services under highland - lowland economic links }\end{array}$ \\
\hline $\begin{array}{l}\text { Strengthening and local participation in } \\
\text { harnessing of mountain niche }\end{array}$ & $\begin{array}{l}\text { - Complement nature-endowed niche with human made niche facilities } \\
\text { - Ancillary role in harnessing of key resources (e.g., hydropower, NTFPs etc.) by external agencies }\end{array}$ \\
\hline Arresting exclusion process & $\begin{array}{l}\text { - Partnership in enterprises based on assets taken from local people } \\
\text { - } \quad \text { Adequate compensation for unavoidable exclusion (i.e., loss of assets, opportunities due to global process) }\end{array}$ \\
\hline $\begin{array}{l}\text { Integration of mountain economies with } \\
\text { rest of the world on equal terms }\end{array}$ & $\begin{array}{l}\text { - } \quad \text { Capacity building } \\
\text { - } \quad \text { Partnership with external agencies }\end{array}$ \\
\hline Global advocacy and concessions & $\begin{array}{l}\text { - With special problems of mountains, provision for special window (exceptions to WTO rules) to help } \\
\text { mountain areas } \\
\text { - International concern and mobilization/dialogue supporting mountains for their contributions to global } \\
\text { commons (fresh water, biodiversity, hydropower helping downstream communities and economies) }\end{array}$ \\
\hline
\end{tabular}

enhance adaptation options against vulnerabilities is a crucial requirement, because it is the "place-based" situation that finally reflects the operational dimension of the problems and relevance and effectiveness of the planned solutions.

Finally, an important step in designing adaptation strategies is to look at the potential opportunities associated with the risk or vulnerability promoting changes. This is specifically, so in the case of economic globalization which carries both risks and potential opportunities for mountain areas and communities, as alluded to earlier.

Specific areas for identification of options against vulnerabilities Given the broad framework of basic considerations mentioned above some steps may be suggested to help reduce the vulnerability promoting (option reducing) impacts of global environmental change (cumulative type ones) and economic globalization. They are summarized in Tables 7 and 8. Even though scattered evidence on these aspects is already emerging (Jodha 2000), but systematic research on the indicated measures and their implementations will go a long way in enhancing livelihood options for mountain communities to adapt to emerging vulnerabilities more (Jodha 2000) effectively.

\section{This paper is a revised version of a paper presented at international workshop on "Adaptation to Climate Change in Mountain Ecosystems: Bridging Research and Policy", organized by IGES, J apan and HCC, Nepal, at Kathmandu, 3-5 March 2004.}

NS Jodha is senior Associate Scientist of International Center for Integrated Mountain Development (ICIMOD), Lalitpur, NEPAL.E-mail:njodha@icimod.org.np

\section{References}

Blaikie P and H Brookfield. 1987. Land degradation and society. London and New York: Methuen. $296 \mathrm{p}$

ICIMOD. 1993. The role of extreme weather events, mass movements, and land use changes in increasing natural hazakrds. A Report of the Preliminary Field Assessment and Workshop on Causes of the Recent Damage Incurred in South-Central Nepal; 1993 July 19-20. Kathmandu: International Center for Integrated Mountain Development (ICIMOD). $164 \mathrm{p}$

IPCC (Intergovernmental Panel on Climate Change). 2001. Climate Change 2001: Synthesis report, third assessment report of the Intergovernmental Panel on Climate Change. Cambridge: Cambridge University Press
Jodha NS. 1989. Potential strategies for adopting to greenhouse warming: Perspectives from the developing world. In: Rosenberg NJ, WE Easterling, PR Crosson and J Darmstadter (eds), Greenhouse warming: Abatement or adaptation. Washington: Resources for the Future. p 47-158

Jodha NS, M Banskota and T Pratap (eds). 1992. Sustainable mountain agriculture, 2 vols. Delhi: IBH Publishing Company. $807 \mathrm{p}$

Jodha NS and S Shrestha. 1993. Sustainable and more productive Mountain Agriculture: Problems and prospects.A paper preseted at ICIMOD's 10th Anniversary, International symposium on 'Mountain environment and development'. Kathmandu, Nepal

Jodha NS. 1995. The Nepal middle mountains. In: Kasperson JX, RE Kasperson and BL Turner II (eds). Regions at risk: Comparisons of threatened environments. Tokyo: United Nations University Press. p 140-185

Jodha NS. 1998. Reviving the social system-ecosystem links in the Himalayas. In: Berkes F and C Folke (eds), Linking social and ecological systems: Management practices and social mechanisms for building resilience. Cambridge, UK: Cambridge University Press. p 285-310

Jodha NS. 2000. Poverty alleviation and sustainable development in mountain areas: Role of highland-lowland links in the context of rapid globalization. In: Banskota M., TS Papola, and J Richter (eds), Growth poverty alleviation and sustainable resource management in mountain areas of South Asia. Kathmandu: International Center for Integrated Mountain Development (ICIMOD). p 541-570

Jodha NS. 2001a. Poverty and environmental resource degradation: An alternative explanation and possible solutions. In: Jodha NS (ed), Life on the edge: Managing agriculture and community resources in fragile environments. Delhi: Oxford University Press

Jodha NS. 2001b. Global change and environmental risks in mountain ecosystems. In: Kasperson JX and RE Kasperson (eds), Global environmental risks. Tokyo: United Nations University and London: Earth Scan. p 306-342

Jodha NS. 2002. Globalization and fragile mountains. An exploratory research report submitted to MacArthur Foundation. Kathmandu, Nepal

Kasperson JX, RE Kasperson and BL Turner, II (eds). 1995. Regions at risk: Comparison of threatened environments. Tokoy: United Nations University. $588 \mathrm{p}$

Kasperson JX and R Kasperson (eds). 2001. Global environmental risk. Tokyo: United Nations University and London: Earthscan. $512 \mathrm{p}$

Tropping JC, A Qureshi and SA Sherer. 1990. Implication of climate change for the Asian and Pacific Region. Paper submitted to the Asia Pacific Seminar on Climate Change, 1991 January 23-26, Nagoya, Japan. Washington: Climate Institute

Turner BL, RE Kasperson, WB Meyer, KM Dow, D Golding, JX Kasperson, RC Mitchell and SJ Ratick. 1990. Two types of global environmental change: Definitional and spatial-scale issues in their human dimension. Global Environmental Change 1(1, December): 14-22 